\title{
Practice of the nurses in breastfeeding-friendly units of basic health
}

\author{
Atuação dos enfermeiros em unidades básicas de saúde amigas da amamentação
}

\author{
Actuación de los enfermeros en unidades básicas de salud amigas de la lactancia materna
}

Felipe César Stabnow Santos ${ }^{1}$, Ana Cristina Teixeira Cyrino ${ }^{2}$, Floriacy Stabnow Santos ${ }^{3}$, Marcelino Santos Neto ${ }^{3}$, Fabiana Nara Ambrosio Abrahão ${ }^{4}$

The Breastfeeding-Friendly Basic Units Initiative is a tool that helps to encourage breastfeeding. This study aimed at describing the nurses' knowledge on the Ten Steps of the Breastfeeding-Friendly Basic Units Initiative, as well as verifying educational activities and encouraging the breastfeeding promoted by nurses, assessing the same opinion about their own care and factors that hinder the improvement of service. Descriptive study with a quantitative approach. We interviewed 20 health professionals in Anapolis, GO, Brazil. The results showed that most nurses received training on breastfeeding, however, the number of lectures, individual and group meetings held to publicize the issue were insufficient. The Ten Steps of the Breastfeeding-Friendly Basic Units Initiative were not known by the majority, who were dissatisfied with the governmental incentives. Nurses must develop actions to promote and support breastfeeding.

Descriptors: Family Health; Breast Feeding; Nursing.

A Iniciativa Unidade Básica Amiga da Amamentação é uma ferramenta que contribui para incentivar o aleitamento materno. Objetivou-se descrever o conhecimento dos enfermeiros sobre os Dez passos da Iniciativa Unidade Básica Amiga da Amamentação, bem como verificar as atividades educativas e de incentivo ao aleitamento materno realizadas pelos enfermeiros, avaliando a opinião dos mesmos sobre o próprio atendimento e os fatores que dificultam a melhoria do serviço. Estudo descritivo, com abordagem quantitativa. Foram entrevistados 20 profissionais em Anápolis, GO, Brasil, em 2009. Os resultados mostraram que a maioria dos enfermeiros recebeu capacitação sobre amamentação, entretanto, o número de palestras, reuniões individuais e em grupo realizadas para divulgar o tema foi insuficiente. Os Dez Passos da Unidade Básica Amiga da Amamentação não eram conhecidos pela maioria, que estava insatisfeita com os incentivos do governo. Os enfermeiros devem desenvolver ações para incentivar e apoiar a amamentação.

Descritores: Saúde da Família; Aleitamento Materno; Enfermagem.

La Iniciativa Unidad Básica Amiga de la Lactancia Materna es herramienta que ayuda fomentar la lactancia materna. El objetivo fue describir el conocimiento de enfermeros cuanto a los Diez Pasos de la Iniciativa Unidad Básica Amiga de la Lactancia Materna, verificar las actividades educativas y de incentivo a la lactancia materna, realizadas por enfermeros, evaluando opiniones sobre su atención y factores que dificultan la mejora del servicio. Estudio descriptivo, con enfoque cuantitativo. Fueron entrevistados 20 profesionales en Anápolis-GO, Brasil, en 2009. Los resultados señalaron que la mayoría de los enfermeros recibieron capacitación sobre lactancia materna, sin embargo, el número de conferencias, reuniones individuales y colectivas realizadas para conocer el tema eran insuficientes. Los Diez Pasos de la Iniciativa Unidad Básica Amiga de la Lactancia Materna no eran conocidos por la mayoría, que se mostraron insatisfechos con los incentivos del gobierno. Los enfermeros deben desarrollar acciones para incentivar y apoyar la lactancia materna.

Descriptores: Salud de la Familia; Lactancia Materna; Enfermería.

\footnotetext{
${ }^{1}$ Hospital Universitário de Brasília. Brasília, DF, Brazil.

${ }^{2}$ Hospital Santa Luzia. Brasília, DF, Brazil.

${ }^{3}$ Universidade Federal do Maranhão. Imperatriz, MA, Brazil.

${ }^{4}$ UniEvangélica. Anápolis, GO, Brazil.
} 


\section{Introduction}

The Maternal Breastfeeding (MB) is recommended by organizations such as the Health Department and the World Health Organization, among others, due to the several advantages for the mother and the baby pointed out by various scholars of the subject ${ }^{(1-2)}$. The exclusive maternal breastfeeding is indicated up to six months of age of the child, when this feeding must be complemented by other types of food until he is two years old or more ${ }^{(3)}$.

The research of prevalence of maternal breastfeeding in the Brazilian capital and in the Federal District showed a significant improvement in the situation of this practice between 1999 and 2008. However the targets, proposed by the World Health Organization and the Health Department have not been reached ${ }^{(4)}$. Studies have shown a reduction in the time of exclusive maternal breastfeeding and such procedure is justified by several factors, such as the lack of information of the women during prenatal care. The precarious socio-economical conditions and the lack of infrastructure are still decisive factors for the sensitization of the importance of the practice of maternal breastfeeding in the needy population ${ }^{(5)}$. Despite the scientific evidences of the superiority of maternal milk on other types of milk, the number of women who breastfeed her children is still low ${ }^{(4)}$.

Breastfeeding depends on factor which can be related both to the mother as well as to the child. The early weaning can be linked to complaints such as sick mothers, work outside the house, lactation disorders and the refusal of the baby in catching the breast, besides stress ${ }^{(6)}$.

The process of breastfeeding, although apparently simple and with singular physiological automatism, requires a complex set of interactional conditions in the social context of the woman and her child. Only the information or the orientations are not enough for the women to be successful in their experience of breastfeeding or for them to be motivated to do $\mathrm{it}^{(2)}$. It is necessary to provide concrete conditions for the mother and their babies to experience this process in a pleasurable and efficient way, once individual, familiar and social factors seem to be challenges to be faced for the success of breastfeeding ${ }^{(7)}$.

The contribution of the Basic Units of Health (BUH) for the promotion, protection and support to maternal breastfeeding has been incipient in its current organization, considering the relevant role of the services, above all in the maternal-infant attention. The current model tends of operationalize the focused practice, especially in the biological dimension, underestimating the approaches which consider the physiological, social and cultural components ${ }^{(8)}$. In turn, the health professionals must guarantee an assistance of quality to the pregnant or puerpera woman, valuing the listening, the clarifying of doubts and the comprehension on their beliefs and taboos, in order to make breastfeeding an act of pleasure and not the opposite ${ }^{(6)}$.

So, the activities of incentive become essential in order to have greater adhesion to the practice of breastfeeding ${ }^{(2)}$, this has a singular value for the promotion of this action thus contributing to revert the low rates of prevalence of this practice in Brazil, especially the maternal breastfeeding up to six months ${ }^{(9)}$. The professionals of the Family Health Strategy (FHS) must know the preventive activities considered priority actions and that the incentive to breastfeeding is presented as one of the main actions in basic attention ${ }^{(5)}$.

The ten steps which contribute for the success of breastfeeding in the BUHs are highlighted: having a rule or a written program on breastfeeding; performing periodical theoretical-practical training of promotion, protection and support for all the staff; orientating the pregnant woman during prenatal on the advantages of the breastfeeding; being attentive to the worries, experiences and doubts the mothers have on the practice of breastfeeding, strengthening their self confidence; orientating as to the importance of breastfeeding in the first half-hour after the delivery and of the permanence of mother-baby binomial in 
the rooming-in; observing the techniques used by the mothers to breastfeed and correct them; orienting the mother as to the method of lactation amenorrhea and other adequate contraceptive methods to breastfeed; encouraging breastfeeding under free demand; advising against the use of artificial dummies to the breastfed children; and incentivizing the formation of groups of support to breastfeeding ${ }^{(10)}$.

The World Health Organization and the United Nations Children's Fund idealized and recommend the ten steps for the success of maternal breastfeeding. In this sense, the Breastfeeding-Friendly Basic Units Initiative, which indicates those ten steps, was successfully implanted in the state of Rio de Janeiro, Brazil in 1999. From 2001 on, the Health Department started to support this initiative which was implanted in other states. In the initiative, the health professionals of the BUHs are trained, and also pregnant women and puerperas received orientation on breastfeeding from prenatal care, besides the support turned to the management of breastfeeding after the child is born ${ }^{(11)}$.

The Breastfeeding-Friendly Basic Units Initiative is a tool that contributes to incentivize breastfeeding in BUHs, delineating an important role of support, in order to make breastfeeding as universal practice, thus significantly contributing for the health and the welfare of the babies, mothers, family and the society ${ }^{(11)}$.

There is a great need of discussion and sensitization of the health professionals on the importance of a program in permanent education in breastfeeding, which would implement the promotion of breastfeeding and, consequently, increase its prevalence and time, besides improving the actions of incentive in the daily activities of the health services ${ }^{(12)}$. In this sense, a study was developed with the objective to describe the knowledge of the nurses on the Ten Steps of Breastfeeding-Friendly Basic Units Initiative, to verify the activities of health education and incentive to breastfeeding taught to the population by the nurses in the BUHs, besides evaluating the opinion of the nurses on their own assistance and identifying the factors which male the improvement of service difficult.

\section{Method}

It is a descriptive study, with quantitative approach made in 20 BUHs, with the nurses in the FHS, linked to County Health Department, of the county of Anapolis, Goiás, Brazil. In these units activities linked to the Breastfeeding-Friendly Basic Units Initiative were developed, with the participation of the nurse, the doctor and the nursing assistant.

Twenty nurses participated in the study, representatives of each unit of health. The choice was at random, obtained by accessibility, acceptance and availability to participate in the research. Being a graduate nurse and working in the FHS for at least three months were considered criteria of inclusion.

The data collection was made at the health professionals work site in January 2009, a questionnaire with semi structured items was used. The instrument was delivered to the participants, which was answered without the presence or influence of the researcher.

Specifically to elucidate the purpose of the study, the participants were questioned regarding the knowledge of the Ten Steps of the BreastfeedingFriendly Basic Units Initiative. The answers were classified according to the correct indication of the steps, with the following descriptors: good (from 7 to 10 steps); moderate (from 4 to 6 steps); bad (from 1 to 3 steps) and terrible (no step). The factors which made difficult the development of the activities of incentive to breastfeeding and the opinion on their own assistance were also investigated.

The data were grouped in a Excel 2003 for Windows spreadsheet for codification of the data. Afterwards they were organized, analyzed and interpreted quantitatively.

The development of the study complied with the national rules of ethics in research involving 
human beings. The project was submitted to the Committee of Ethics in Research of the Centro Universitário de Anápolis (UniEvangélica), whose approval is described in protocol 58/2008.

\section{Results}

Twenty nurses who provided information concerning the steps of the Breastfeeding-Friendly Basic Units Initiative participated in the study. As shown in table 1 , most of the nurses (12; 60.0\%) showed bad knowledge concerning the steps of the initiative.

Table 1 - Development of the nurses of FHS as to the knowledge of the Ten Steps of Breastfeeding-Friendly Basic Units Initiative

\begin{tabular}{lc}
\hline Development of knowledge & $\mathbf{n}(\%)$ \\
\hline Bad & $12(60.0)$ \\
Terrible & $4(20.0)$ \\
Moderate & $2(10.0)$ \\
Good & $2(10.0)$ \\
\hline
\end{tabular}

Concerning the acquisition of specific knowledge about breastfeeding, $80 \%$ of the participants had received information on the theme, through the participation in trainings, courses, workshops (of short or long length), among other means of professional training. However, $20 \%$ did not inform habilitations directed to the theme.

As to the interval of time in which the activities or orientations of incentive to breastfeeding were made in BUHs or the time in which the last activity was made, in most cases, the nurses (70\%) perform activities fortnightly; the other (30\%) had not done that for at least three months, even 1 year. It is believed that the activities of incentive to breastfeeding should be routinely performed, more often and at shorter intervals of time.

As to number of activates turned to the orientation about breastfeeding, $60 \%$ of the nurses developed one activity, $10 \%$ two activities, $20 \%$ three activities and 10\% reported to developed four activities. It is still noticed that the activities performed represented educational actions such as lectures and individual or group meetings; nursing appointments focusing the subject; development of home visits; and professional training. The number of educational activities was reduced, which was interpreted by the researches as related to the development of one professional team. The maternal difficulties, facing exclusive breastfeeding are known by the nurses. It is understood that breastfeeding could be stimulated and, consequently, would obtain success in the offer of breastfeeding to their children, if there were previous clarifying of its importance to the mothers.

Regarding the opinion of the nurses on their own assistance, it was classified as excellent, good, regular and bad. Taking into consideration the answers, $10 \%$ answered that the assistance was bad; $20 \%$ regular; and $70 \%$ good. None of the health professionals considered the assistance excellent, facing the improvement of the exclusive breastfeeding among the user assisted in their area.

Regarding the factor that made difficult the performance of the activities of incentive to breastfeeding, the following were highlighted: lack of transportation to provide home visit, lack of educational material on breastfeeding, lack of adhesion of the community to the educational activities, lack of financial resources to guarantee the presence of the population in meetings and lectures, and lack of financial incentive by the government. The nurses still reported the lack of interest by part of the population regarding the adhesion to breastfeeding, which did not know how to take advantages of the opportunities and educational activities promoted by the BUH, even those mothers who most needed the support.

The lack of government incentive was shown as a difficulty by $50 \%$ of the subjects; $10 \%$ indicated lack of professional interest; and $40 \%$ pointed both the situations as difficulties of the actions of the professionals. 


\section{Discussion}

The use of the instruction recommended by Breastfeeding-Friendly Basic Units Initiative, associated to adequate methodologies, reveals the important role of support which these units can assume in order to make breastfeeding a universal practice, thus significantly contributing for the health and the welfare of the babies, the mother, family and community ${ }^{(12)}$. Despite the fact that the attention to the child in the FHS is a priority, no specific study was found which could evaluate the knowledge of the nurses on the Ten Steps of Initiative, thus making difficult a counter position of the findings in this topic.

In the health net of the Rio de Janeiro county, Brazil, when studying the efficacy of the Initiative, it was evident that the strategy contributed for the increase of the prevalence of breastfeeding and exclusive maternal breastfeeding and for the decrease of the appointment whose main complaints were diarrhea in infants under 1 year old assisted at BUHs. The Initiative in basic attention in this study (conventional units and family health teams), is characterized by a transforming tool of processes of work in the county. Under the conception of the health professionals, there was a significant impact in the adoption and maintenance of maternal breastfeeding and complemented breastfeeding up to two years of life or more ${ }^{(13)}$.

In Montes Claros (MG, Brazil), the knowledge of promoting breastfeeding in teams of FHS was evaluated ${ }^{(14)}$. The performance was divided into four theme areas. There was a performance superior to $80 \%$ for the nurses when they were dealing with the advantages of breastfeeding. Regarding the correct technique of breastfeeding, for the general knowledge on maternal milk, cares with the breast and management of the main problems, the performance was $60 \%, 82 \%$ and $48 \%$, respectively. Such results suggest that there is theoretical knowledge, but this is reduced when associated to the practical performance.

With the objective to evaluate the rates of breastfeeding concerning the work of the health professionals of FHS, in the county of Moreno, PE, Brazil ${ }^{(15)}$, it was evident that even among the professionals of the area of health who work in basic attention and contribute for the health promotion through daily action of incentive to natural breastfeeding, the time of exclusive maternal breastfeeding is still far from what is recommended by the World Health Organization.

In the present research the time in which the activities or orientation of incentive to breastfeeding were made in the BUHs, ranged from 15 days to 1 year. This can be related to the lack of preparation and of interest of the health professionals in promoting satisfactory interventions besides configuring lack of credibility in the offer of essential breastfeeding to the health of the baby, thus making difficulty the education in health and the incentive to mothers assisted by FHS. So it is important that the health professionals show commitment in the pursuit for theoretical knowledge and in the continuous assistance to the clients who presented difficulties at the time of breastfeeding.

The diffusion of information of maternal breastfeeding constitutes an important role for all the health professionals, especially the nurse, who must offer adequate and continuous support for the binomial mother/baby. This information must be publicized in a personalized and humanized manner ${ }^{(16-17)}$. The need of this offer is understood. However, if this support is not available in the BUHs, a process of maternal suffering can be initiated, such as the mammal engorgement and fissure in the nipples. It was highlighted that even the cry of the newborn can lead them to believe in the myth there their milk is weak or insufficient. Strategies must be developed to offer the mothers enlightenment which makes possible the emotional-theoretical support, so they can take the decision to breastfeed ${ }^{(18)}$.

Therefore it is perceived that there is a lack of orientation for the mothers to the correct technique and adequate management of the main problems which cause lack of adhesion to breastfeed. Under this perspective, the prenatal assistance is insufficient to 
establish a high level of information on breastfeeding and it is vital to have postpartum assistance and during the whole period of breastfeeding ${ }^{(19)}$.

The health professionals must perform activities of support to maternal breastfeeding, whatever the condition of work, the level and the training of governmental incentive may be. More important than the early begging and the frequency to the prenatal care appointments are the attitudes of the health professionals, considered indirect indicators of the quality of the assistance rendered. It is fundamental that the woman feels adequately assisted in her doubts and difficulties, to assume the role of mother, and provide breastfeed to her son safely ${ }^{(6)}$

Breastfeeding must be a learned behavior and exercised by the women; the health professionals must be stimulated, encouraged and supported, in order to maintain the indicator of breastfeeding in high levels ${ }^{(20)}$.

So that the health professionals can incentivize the mother during the breastfeeding, there is the need of training on maternal breastfeeding. Associated to that, they must deprive of the interactions, making possible the use of abilities of counseling, and also to know the context of their community. A greater investment in training turned to the handling of breastfeeding, results in the use of the potential area of FHS to promote and support breastfeeding in the communities $^{(6)}$.

\section{Final Considerations}

It was verified through this research, that in most cases, the nurses do not prioritize actions turned to the incentive of maternal breastfeeding. This becomes explicit, keeping in mind the little different activities which are made, and the lack of domain and security facing this matter. Many times the activities performed with the population are not effective for the incentive of the breastfeeding, once for this purpose, pertinent, dynamic and continuous activities with quality are necessary, which did not happen in the research environment.

The health professionals justify their absences or the little activities of support and promotion to breastfeeding mentioning the lack of adequate input for the performances of the educational activities turned to the promotion of breastfeeding and even the lack of financial incentive.

Despite verifying the little incentive to breastfeeding, many believe that this is sufficient, once they believe the service rendered to the family regarding breastfeeding is good. Even having the training of the health professionals on the handling of maternal milk, the Ten Steps of the BreastfeedingFriendly Basic Units Initiative are still unknown to some, which makes the good assistance difficult.

The professional training of the health team is urged to guarantee the participation in an effective way, stimulating constantly the needs of the population, especially the attention to the binomial mother-son. It is known that this training, allied to the good management, can lead to the ideal use of the potentiality of the team.

This study calls attention to the strategies of promotion, support and incentive to maternal breastfeed, actually implemented and that health professionals become motivated to publicize breastfeeding. Changes must happen and start a new phase of service rendered, which emphasize breastfeeding as a priority.

There are, however, the needs to guarantee that the governmental proposals are developed by the health professionals. It is possible to guarantee a satisfactory assistance turned to breastfeeding if there is a commitment from health management.

\section{Collaborations}

Santos FCS contributed for the conception of the work, data collection, analysis, interpretation of the data and writing of the article. Cyrino ACT contributed for the writing of the article and final approval of the 
version to be published. Santos FS contributed for the writing of the article, interpretation of the data and final approval of the version to be published. Santos Neto $M$ contributed for the writing of the article and final approval of the version to be published. Abrahão FNA contributed for the conception of the work, analysis and interpretation of the data.

\section{References}

1. Antunes LS, Antunes LAA, Corvino MPF, Maia LC. Amamentação natural como fonte de prevenção em saúde. Ciênc Saúde Coletiva. 2008; 13(1):103-9.

2. Caminha MFC, Serva VB, Anjos MMR, Brito RBS, Lins MM, Batista Filho M. Aleitamento materno exclusivo entre profissionais de um Programa Saúde da Família. Ciênc Saúde Coletiva. 2011; 16(4):2245-50.

3. Levy L, Bértolo H. Manual do Aleitamento Materno [Internet]. Fundo das Nações Unidas para a Infância (UNICEF). Comité Português para a UNICEF. Comissão Nacional Iniciativa Hospitais amigos dos Bebés. 2008 [citado 2014 fev 17]. Disponível em: http://www.unicef.pt/docs/manual_aleitamento_2012.pdf

4. Ministério da Saúde (BR). II Pesquisa de prevalência de aleitamento materno nas capitais brasileiras e Distrito Federal. Brasília, DF: Ministério da Saúde; 2009.

5. Fujimori E, Nakamura E, Gomes MM, Jesus LA, Rezende MA. Aspectos relacionados ao estabelecimento e à manutenção do aleitamento materno exclusivo na perspectiva de mulheres atendidas em uma unidade básica de saúde. Interface Comun Saúde Educ. 2010; 14(33):315-27.

6. Araújo OD, Cunha AL, Lustosa LR, Nery IS, Mendonça RCM, Campelo SMA. Aleitamento materno: fatores que levam ao desmame precoce. Rev Bras Enferm. 2008; 61(4):488-92.

7. Rocha NB, Garbin AJI, Garbin CAS, Moimaz SAS. $\mathrm{O}$ ato de amamentar: um estudo qualitativo. Physis. 2010; 20(4):1293-305.

8. Frota MA, Mamede ALS, Vieira LJES, Albuquerque CM, Martins MA. Cultural practices about breast- feeding among families enrolled in a Family Health Program. Rev Esc Enferm USP. 2009; 43(4):890-6.

9. Ministério da Saúde (BR). Secretaria de Atenção à Saúde, Departamento de Atenção Básica. Saúde da criança: nutrição infantil. Aleitamento materno e alimentação complementar. Brasília: Ministério da Saúde; 2009.

10. Martins RMC, Montrone AVG. Implementação da Iniciativa Unidade Básica Amiga da Amamentação: educação continuada e prática profissional. Rev Eletr Enferm [periódico na Internet]. 2009 [citado 2013 set 13]; 11(3):545-53. Disponível em: http://www.fen.ufg.br/revista/v11/n3/ v11n3a11.htm

11. Christoffel MM, Votto MG, Allevato CG, Ambrósio MDV, Araújo AS. Práticas de amamentação de puérperas na consulta de enfermagem neonatal em unidade básica de saúde. Rev Min Enferm. 2009; 13(2):202-8.

12. Fonseca-Machado MO, Haas VJ, Stefanello J, Nakano AMS, Gomes-Sponholz F. Breastfeeding: knowledge and practice. Rev Esc Enferm USP. 2012; 46(4):809-15.

13. Cardoso LO, Vicente AST, Damião JJ, Rito RVV. The impact of Implementation of the Breastfeeding Friendly Primary Care Initiative on the prevalence rates of breastfeeding and causes of consultations at a basic healthcare center. J Pediatr. 2008; 84(2):147-53.

14. Caldeira AP, Aguiar GN, Magalhães WAC, Fagundes GC. Conhecimento e práticas de promoção do aleitamento materno em equipes de Saúde da Família em Montes Claros, Minas Gerais, Brasil. Cad Saúde Pública. 2007; 23(8):1965-70.

15. Silva CF, Araujo PM, Bittencourt RA. Aleitamento materno entre profissionais do programa de saúde da família. Rev Enferm UFPE on line [periódico na Internet]. 2008 [citado 2014 fev 17]; 2(2):171-6. Disponível em: http://www.revista.ufpe.br/revistaenfermagem/index.php/revista/article/viewFile/421/pdf_370

16. Freitas GL, Joventino ES, Aquino OS, Pinheiro AKB, Ximenes LB. Avaliação do conhecimento de gestantes acerca da amamentação. Rev Min Enferm. 2008; 12(4):461-8. 
17. Uchoa JL, Sales AAR, Joventino ES, Ximenes LB. Indicator $\mathrm{s}$ of quality of prenatal assistance: pregnants at family's health unit. Rev Enferm UFPE on line. [periódico na Internet]. 2010 [citado 2014 fev 17]; 4(1):212-20. Disponível em: http://www. revista.ufpe.br/revistaenfermagem/index.php/ revista/article/viewArticle/724.

18. Olimpio DM, Kochinski E, Ravazzani EDA. Fatores que influenciam no aleitamento materno e desmame precoce em mães adolescentes e adultas. Cad Esc Saúde. 2010; 3:1-12.
19. Andrade MP, Oliveira MIV, Bezerra Filho JG, Bezerra MGA, Almeida LS, Veras MAC. Desmame precoce: vivencia entre mães atendidas em unidade básica de saúde em Fortaleza-Ceará. Rev Rene. 2009; 10(1):104-13.

20. Bonilha ALL, Schmalfuss JM, Moretto VL, Lipinski JM, Porciuncula MB. Capacitação participativa de pré-natalistas para a promoção do aleitamento materno. Rev Bras Enferm. 2010; 63(5):811-6. 